DOI: $10.15290 / \mathrm{bsl} .2014 .05 .06$

Jacek Kaczmarek

Zakład Geografii Miast, Uniwersytet Łódzki

e-mail: jacek.kaczmarek@geo.uni.lodz.pl

\title{
Literackie zapisywanie przestrzeni w kontekście trwania miasta na przykładzie Dublina
}

Czas jednak sam w sobie nie daje się spostrzec; to, co trwa w zjawiskach, stanowi przeto podłoże wszelkiego czasowego określenia [...].

Immanuel Kant, Krytyka czystego rozumu ${ }^{1}$

\section{Geografia, przestrzeń, literatura}

Michaił Bachtin podejmował w swoich pracach literaturoznawczych zagadnienia przestrzeni i czasu. Efektem długoletniego twórczego wysiłku było przygotowanie koncepcji chronotopii ${ }^{2}$, opartej na założeniu, że przestrzeń i czas są koniecznym wyobrażeniem umysłu i nie można ich wykazać empirycznie. Opierając się na Kantowskim ujęciu krytycznym, Bachtin w następnym kroku teoriopoznawczym wskazał na totalną realność przestrzeni i czasu w literaturze oraz w rzeczywistym, polifonicznym świecie. Bohater literacki bywa bowiem zanurzony w konkretnym czasie i przestrzeni, ale także autor, wraz ze swoim dziełem, jest unoszony przez cywilizacyjną rzekę czasu, która przepływa przez krainy zmienne historycznie ${ }^{3}$. Natomiast w naukach geograficznych Jean-Paul Ferier zaproponował ideę topochronii, czyli wyko-

\footnotetext{
${ }^{1}$ I. Kant, Krytyka czystego rozumu, przeł. R. Ingarden, Kęty 2001, s. 227.

2 M. Bachtin, Problemy literatury i estetyki, przeł. W. Grajewski, Warszawa 1982.

3 N. Bemong i in., Bakhtin's Theory of the Literary Chronotope: Reflections, Applications, Perspectives, Gent 2010.
} 
rzystania tekstu literackiego do wyjaśnienia i zrozumienia przestrzeni ${ }^{4}$. Topochronię można określić także jako analizę "trwania miejsca” (terytorium). Przestrzeń ma bowiem tę właściwość, że następuje w niej akumulacja czasu. Przestrzeń utrwala czas. Analizując przestrzeń miasta, można odczytywać warstwy nakładającego się czasu. Narzędziem użytecznym w odkrywaniu czasu zapisanego w realnej przestrzeni bywa literatura. Koncepcja Bachtina nie jest obca naukom geograficznym. Wykorzystuje się ją do analiz różnorodnych obszarów geograficznych ${ }^{5}$. Również w literaturoznawstwie metodologia geograficzna znajduje zastosowanie w wyjaśnianiu kontekstu zróżnicowania przestrzennego ${ }^{6}$.

Literatura piękna dostarcza bezcennych informacji o przestrzeni miejskiej. W analizie geograficznej dzieła literackiego szczególną rangę zyskuje wyeksponowanie roli przestrzeni, która oddziałuje na proces kreacji artystycznej oraz stanowi ważny materiał faktograficzny, przypomina o przemianach środowiska geograficznego ${ }^{7}$. Przestrzeń w tekstach literackich nie jest tylko tłem opisywanych wydarzeń, ale znaczącym elementem struktury dzieła ${ }^{8}$. Fikcja literacka zostaje wytworzona przez autora, ale jej powstanie zależy od miejsca. Przestrzeń przedstawiona utworów literackich bywa zazwyczaj zakorzeniona w krajobrazie, życiu miast, w wiejskiej tradycji, w pejzażach regionalnych ${ }^{9}$. Literatura piękna jest niczym wspominany przez Vladimira Nabokova atlas ${ }^{10}$ - wyobrażeniowe mapy wędrówki człowieka po meandrach szlaku życiowego. Nawet wielogodzinna podróż po własnym pokoju stanowi swoisty atlas, wewnętrzne itinerarium. Miejsca znaczące można nazwać „kliniką położniczą” wielkiej literatury. Relacje pomiędzy przestrzenią i dziełami literackimi mają charakter zwrotny, ponieważ literatura wpływa także na przekształcenia przestrzeni realnej. W ujęciu chronotopicznym analizy geograficzne pomagają w odsłanianiu sensu dzieła

\footnotetext{
4 J.-P. Ferier, Antee 1. La geographie, ca sert d'abord a parler du territorie o ule megier des geographies, Aix-en-Provence, Edisud 1984.

5 J. Lawson, Chronotope. Story and Historical Geography: Michail Bakhtin and the Space-Time of Narratives, "Antipode", 2011, vol. 43, issue 2, p. 384-412.

6 Zob. np. E. Rybicka, Geopoetyka. Przestrzeń i miejsce we wspótczesnych teoriach i praktykach literackich, Kraków 2014; Od poetyki przestrzeni do geopoetyki, red. E. Konończuk, E. Sidoruk, Białystok 2012; Geografia i metafora, red. E. Konończuk, E. Nofikow i E. Sidoruk, Białystok 2014.

7 J. Kaczmarek, Dublin - labirynt nad rzeka, w: Humanistyczne oblicze miasta, red. D. Jędrzejczyk, Warszawa 2004.

8 A. Majer, Lektura miasta, w: Zbiorowości terytorialne i więzi społeczne, red. P. Starosta, Łódź 1995; Humanistyczne oblicze miasta, red. D. Jędrzejczyk, Warszawa 2004.

9 F. Regard, Topologies of the Self: Space and Life-Writing, "Journal of Literature and the History of Ideas" 2003, nr 1.

10 V. Nabokov, Wykłady o literaturze, przeł. Z. Batko, Warszawa 2001, s. 34-36.
} 
literackiego, natomiast instrumentarium literaturoznawcze umożliwia rozumienie realnej przestrzeni geograficznej w kontekście topochronii. Ujmując rzecz nieco inaczej, chronotopia pozwala zrozumieć literaturę poprzez geografię, a topochronia prowadzi do zrozumienia geografii poprzez literaturę. W kontekście powyższych rozważań, celem artykułu jest ukazanie zależności pomiędzy kreacją artystyczną, która ma korzenie w realnym mieście, a jej odczytaniem w konkretnej przestrzeni geograficznej. Autor kreuje przestrzeń poprzez narrację; czytelnik zaproszony do lektury odczytuje słowa i następnie wyrusza $\mathrm{w}$ podróż, aby w realnej przestrzeni geograficznej dostrzec przedstawione $\mathrm{w}$ dziele obrazy. Ich odnalezienie konstytuuje trwanie miasta.

Mamy zatem do czynienia z kołem hermeneutycznym, w które włączona zostaje literatura i geografia na wzór Gadamerowskiej metody rozumienia. Aby zrozumieć literaturę, trzeba odkryć geografię - aby odkryć geografię, należy zrozumieć literaturę. Chronotopia przechodzi w topochronię i odwrotnie. Mówiąc metaforycznie, czas kroczy w przestrzeni, a przestrzeń przemierza czas.

Fikcja literacka, geografia przedstawiona w niej pozostawiły ślad w rzeczywistym krajobrazie Dublina („Istnieje grupa osób, które obchodzą tak zwany przez nie Dzień Blooma - 16 czerwca" $\left.{ }^{11}\right)$, Pragi, Paryża, Wiednia, Londynu, Manchesteru czy Wyspy Księcia Edwarda ${ }^{12}$. Przestrzeń metropolitalna była z kolei źródłem wielkich miejskich narracji. Miasto wyobrażone przenikało obszary rzeczywiste, $\mathrm{np}$. $\mathrm{w}$ znakomitych opowieściach Jamesa Joyce'a i Virginii Woolf. Również monolog wewnętrzny bohaterów rozwijany jest na tle pejzażu wyobrażonego, będącego nie tylko fantazją, lecz odzwierciedleniem rzeczywistego krajobrazu Dublina czy Londynu ${ }^{13}$. Utwory Joyce'a charakteryzują się wyjątkową, a nawet obsesyjną, precyzją topograficzną. Bohaterowie jego powieści konstruują pejzaże wewnętrzne w realnej przestrzeni Dublina. Fikcja literacka Joyce'a stanowi precyzyjny zapis wydarzeń uwarunkowany czasoprzestrzennymi parametrami geograficznymi. Mimo nowatorskich zabiegów narracyjnych, czas upływa w równym rytmie fizycznych minut, a monologi wewnętrzne mieszkańców Dublina nie wykraczają poza rzeczywiste wymiary przestrzeni urbanistycznej. W liście do brata Stanislausa z 24 września 1905 roku Joyce napisał: „Kiedy zdasz sobie sprawę, że Dublin jest stolicą od tysiąca lat, że jest «drugą» metropolią Imperium Bry-

11 Z listu Joyce'a do Harriety Shaw Weaver, 27 czerwca 1924. Zob. J. Joyce, Listy, t. 2, przeł. M. Ronikier, Kraków 1986, s. 125-126.

12 Atlas literatury, red. M. Bradbury, przeł. A. Błasiak i in., Warszawa 2002.

13 J. Johnson, Literary geography: Joyce, Woolf and the city, "City” 2000, nr 2. 
tyjskiego, że wreszcie jest on trzykrotnie niemal większy od Wenecji - musi Ci się wydać dziwne, że do tej pory żaden artysta nie ukazał go światu"14.

W przestrzeniach miejskich toczą się losy bohaterów powieści. Krajobrazy miejskie odciskają piętno na dziejach człowieka, który pozostawia ślady w przestrzeni, przemierzając szlak swojego życia. Czytelnicy i badacze wędrują wytyczonymi drogami i próbują odnaleźć pozostawione ślady ${ }^{15}$. Teksty literackie Joyce'a tworzą nową przestrzeń Dublina, kreują krajobraz literacki miasta ${ }^{16}$. W analizach przestrzeni urbanistycznej przedstawiano Manchester, Montreal, Sydney, a także miasta wyobrażane lub obiecane ${ }^{17}$. W realnych przestrzeniach staramy się dostrzec klucz do zrozumienia dzieł literackich, a także samych siebie. Trasy badawcze prowadzą przez wiele miast. Nie tylko miasta wywierają wpływ na życie twórców, ale autorzy i bohaterowie ich literackich kreacji kształtują nowe znaczenia przestrzeni, także tych przez nich opuszczonych (np. Petersburg w życiu i twórczości Josifa Brodskiego ${ }^{18}$ ). Artysta maluje portret miasta, a w historii życia artysty dostrzec można jego „przestrzenne ślady". Biografia zatopiona jest w topografii. Każde życie ma bowiem własną geografię, która zostaje zapisana i następnie bywa odczytywana $\mathrm{z}$ kart dzieła literackiego.

\section{Przestrzeń przedstawiona w narracji}

W Dublińncykach, Portrecie artysty z czasów młodości, Ulissesie, Finneganów trenie przestrzeń przedstawiana bywa $\mathrm{w}$ dwu odsłonach. W pierwszej czytelnik wiedziony jest przez realny świat, w którym rozgrywają się losy bohaterów. Druga to przestrzeń przedstawiona w narracji. Autor wyznacza jej porządek, dynamikę, strukturę oraz kody znaczeniowe. W utworach Joyce'a obie warstwy przestrzenne nakładają się na siebie, przenikają się wzajemnie, aby w efekcie kreacji artystycznej utworzyć niepowtarzalną, polifoniczną całość19. Osią kompozycyjną w organizacji przestrzeni Dublina jest rzeka Liffey. Podążając od morza wzdłuż jej nabrzeży w głąb miasta, znajdujemy

\footnotetext{
14 J. Joyce, Listy, t. 1, s. 77.

15 P. Paziński, Labirynt i drzewo. Studia nad „Ulissesem” Jamesa Joyce’a, Kraków 2005; P. Paziński, Dublin z Ulissesem, Warszawa 2008.

16 N.C. Johnson, Fictional journeys: paper landscapes, tourist trails and Dublin's literary texts, "Social \& Cultural Geography" 2004, nr 1.

17 P. Preston, P. Simpson-Housley, Writing the city. Literature and the Urban Experience, London 1994.

18 J. Brodski, Z wierszy petersburskich, "Zeszyty Literackie” 2003, nr 3.

19 I. Pindar, Joyce, London 2004.
} 
kolejno obiekty ważne dla jego funkcjonowania: port i Urząd Celny, gmach Czterech Trybunałów (Sądy), destylarnię whiskey Jamesona, wreszcie browary Guinessa. Prostopadle do osi wschód - zachód, jaką tworzy rzeka, po obu jej stronach na północy i południu usytuowane są dzielnice usługowe: handlowe, rozrywkowe, muzea, galerie, biblioteki, parki oraz uniwersytet Trinity College. Łączą je mosty, spośród których Ha'penny Bridge znalazł poczesne miejsce $\mathrm{w}$ literaturze ${ }^{20}$.

Osią północnego nabrzeża Liffey jest O'Connell Street z przylegającymi doń kwartałami domów towarowych i teatrów, tamże, w pobliżu, ulokowane jest muzeum Jamesa Joyce'a. Południowe nabrzeże to przede wszystkim kwartały enklawy Temple Bar, ruchliwej strefy różnorodnych etnicznie restauracji, klubów muzycznych, galerii artystycznych i pubów, tworzących centrum rozrywki w mieście. $W$ bezpośrednim sąsiedztwie Temple Bar, wzdłuż Dame street ulokowane są budowle historyczne Trinity College, Dublin Castle oraz budynek dawnego parlamentu (rys. 1).

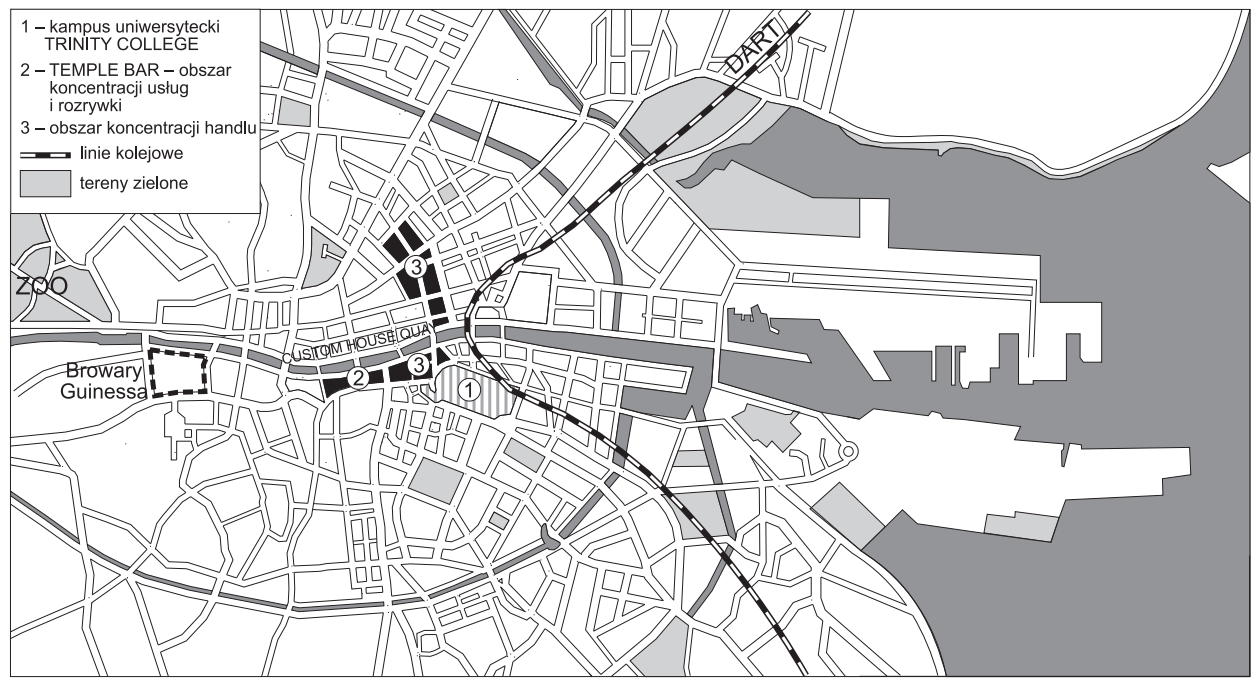

Rys. 1. Dublin - strefa centrum miasta

Pedantycznie odtwarzając obraz stolicy Irlandii, Joyce wykreował oryginalną przestrzeń przedstawioną i to właśnie dzięki niej czytelnik może smakować odkrywanie prawdziwego Dublina. Topografia miasta determinowała kształt tekstu i właśnie za jego sprawą odnajdujemy nowe drogi w nieznanym świecie. Przestrzeń przedstawiona pozwala zrozumieć przestrzeń rzeczy-

20 M. Caulfield, Ireland, Dublin, London 1997. 
wistą. Joyce dostrzegał znaczenie analiz geograficznych: "geografia, wydzielana $\mathrm{w}$ szczupłych dawkach $\mathrm{w}$ szkole, stopniowo przyobleka się $\mathrm{w}$ moich oczach w konkretny kształt [...]"21.

Konstruując przestrzeń przedstawioną w narracji, Joyce pragnął dotrzeć do uniwersalnej idei człowieka, jego zachowań oraz scenerii ludzkiego dramatu. Artysta nie zamierzał dokładnie malować portretów ludzi na tle realnego Dublina. Migawkowe, porozrzucane okruchy dnia składają się, dzięki geniuszowi Joyce'a, na obraz "całego" człowieka, są intrygującą projekcją jego istoty w wiecznie zmiennej teraźniejszości. Poszukiwanie uniwersalnych znaczeń dokonuje się na drodze indywidualnego doświadczenia. Zamierzeniem autora było ukazanie kondycji człowieka w dziejach świata, poprzez pryzmat życiorysów mieszkańców Dublina.

Dublińczycy („,dni z życia”), rozwijają konsekwentnie ideę, że każdy człowiek przechodzi dokładnie te same etapy ziemskiej egzystencji. Wystarczy zatem przedstawić pojedyncze dni osób różniących się wiekiem, aby otrzymać modelowy obraz ludzkiego życia. W chirurgicznie precyzyjnych opisach Dublina i jego mieszkańców Joyce demaskuje ciągłe tracenie przez bohaterów wiary, nadziei i miłości. Dublińczycy nieustannie przegrywają we wszystkich fazach (dzieciństwo, młodość, dojrzałość, układ społeczny) i beznamiętnie wegetują, trwoniąc życie każdego dnia.

Portret artysty z czasów młodości („,życie w życiu”) jest powieścią autobiograficzną. Dzieje „uwięzionego" artysty zostały mocno osadzone w realiach politycznych i społecznych ówczesnej Irlandii.

Ulisses („życie w jednym dniu”), w którym osiemnastogodzinna wędrówka akwizytora ogłoszeniowego - Leopolda Blooma, symbolizuje całość dziejów zarówno bohatera opowieści, jak i ludzkości. Jorge Luis Borges w utworze poświęconym Joyce'owi napisał: „W jednym człowieczym dniu jest czasu suma cała" ${ }^{22}$. Przestrzeń i czas są w tym ujęciu całością, stanowią część i jednocześnie syntezę ludzkiej geobiografii, którą każdego dnia człowiek odtwarza i konstruuje własne życie. Zagospodarowanie postępującego "teraz" prowadzi do odkrywania istoty całej egzystencji. Codzienne wędrowanie ulicami Dublina porównać można do każdorazowego wyruszania do ziemi obiecanej: „Wyjdź z twojej ziemi rodzinnej i z domu twego ojca, do kraju, który ci ukażę" [Rdz. 12, 1]. Ta podróż z 16 czerwca 1904 roku ma wiele inspiracji. Aby zrozumieć zamierzenia literackie Joyce'a, trzeba wyruszyć w drogę ulicami Dublina z planem miasta, Odyseją i Biblią (tab. 1).

21 J. Joyce, Dublińczycy, przeł. K. Wojciechowska, Warszawa 1991, s. 18.

22 J.L. Borges, James Joyce, przeł. E. Stachura, w: E. Stachura, Wiersze, poematy, piosenki, przekłady, Warszawa 1984, s. 372. 
Tabela 1.

Ulisses - przestrzeń narracji (16 czerwca 1904 roku)

\begin{tabular}{|c|c|c|c|}
\hline L.p. & $\begin{array}{c}\text { Godzina } \\
\text { początkowa }\end{array}$ & $\begin{array}{c}\text { Epizody } \\
\text { na motywach Odysei } \\
\text { (Naganowski 1997) }\end{array}$ & $\begin{array}{l}\text { Epizody według } \\
\text { Leopolda Blooma }\end{array}$ \\
\hline 1 & 8 & Telemach & \\
\hline 2 & 10 & Nestor & \\
\hline 3 & 11 & Proteusz & \\
\hline 4 & 8 & Kalipso & Ofiara całopalenia; święte świętych \\
\hline 5 & 10 & Lotofagowie & Obrzęd Jana \\
\hline 6 & 11 & Hades & Obrzęd Samuela \\
\hline 7 & Południe & Eolia & Urim i Thummin \\
\hline 8 & 13 & Lestrygonowie & Obrzęd Melkizedecha \\
\hline 9 & 14 & Scylla i Charybda & Miejsce święte \\
\hline 10 & 15 & Pływające Skały & Simchat Tora \\
\hline 11 & 16 & Syreny & Shira Shirim \\
\hline 12 & 17 & Cyklop & Całopalenie \\
\hline 13 & 20 & Nauzykaa & Obrzęd Onana \\
\hline 14 & 22 & Helios & Ofiarowanie chleba i wina \\
\hline 15 & Północ & Kirke & Armageddon \\
\hline 16 & 1 & Eumajos & Zespolenie \\
\hline 17 & 2 & Itaka & \\
\hline 18 & & Penelopa & \\
\hline
\end{tabular}

Źródło: opracowanie własne oraz E. Naganowski i I. Pindar ${ }^{23}$.

Poszczególne epizody Ulissesa mogą być interpretowane na wiele innych sposobów. Joyce napisał wspaniałe dzieło otwarte (w toku) i ilekroć czytelnik poszukuje śladu właściwych inspiracji, autor uśmiecha się ironicznie wszak stworzył utwór groteskowy, przewrotny, parodystyczny. Podróż szlakiem Blooma i Dedalusa wymaga podobnego spojrzenia na świat, widziany jako teatr ironii. Język Joyce’a bywa nasycony złośliwością: „Piękna rzecz, wiecie, powiada Yeats, to znaczy, chciałem powiedzieć, powiada Keats" ${ }^{24}$. Autor nie liczy się także z czytelnikiem: bohaterowie przychodzą, zmieniają lokalizację, zaczynają rozmyślać w jednym, a kończą w innym miejscu utworu. Ulisses jest nie tyle dla czytelnika, ile czytelnik jest dla niego.

\footnotetext{
${ }^{23}$ E. Naganowski, Telemach w labiryncie świata. O twórczości Jamesa Joyce'a, Poznań 1997; I. Pindar, Joyce, London 2004.

24 J. Joyce, Ulisses, przeł. Maciej Słomczyński, Bydgoszcz 1992, s. 374.
} 
Finneganów tren („,̇̇ycie poza dniem”) stwarza nadzieję na przebudzenie, ale tylko w marzeniach sennych. W przestrzeni Dublina krążą jednocześnie marzenia wielu dublińczyków. Jedyną drogą pozostaje ucieczka $\mathrm{w}$ marzenia.

Wielkie dzieła rodzą się często z zauroczenia innymi wspaniałymi utworami. Konstrukcja Ulissesa posiada pierwowzór w Odysei; opisywany w nim Dublin jest jednocześnie legendarnym Knossos, a Irlandia homerycką Kretą. Wprawdzie wybitni znawcy literatury wyrażali się negatywnie o paralelnej analizie utworów Homera i Joyce'a. Jak zauważył Nabokov: „Nie ma nic nudniejszego od rozwlekłej i długiej alegorii opartej na zużytym micie"25. Jednakowoż Joyce sugerował przeczytanie dzieła Homera przed przystąpieniem do lektury Ulissesa. "Jeżeli chcesz przeczytać Ulissesa, lepiej kup przedtem lub pożycz z biblioteki Odyseję Homera w przekładzie prozą" - pisał do Józefiny Murray 14 października $1921^{26}$.

Mit kreteński uczynił Joyce motywem autobiograficznych dziejów Stefana Dedalusa. Bohater Portretu artysty z czasów młodości i Ulissesa wędruje ulicami Dublina, które są plątaniną ścieżek prowadzących przez różnorodne obszary miasta. Poznawanie „nocnego miasta” pozwala odkryć mroczny krajobraz miejski i jednocześnie inicjuje penetrację ciemnych stron psychiki młodego człowieka. Labirynt miejski wpływa znacząco na wznoszenie labiryntu wewnętrznego, tzn. labiryntu ludzkiej podświadomości, kompleksów i zahamowań ${ }^{27}$. Ponury Dublin kształtuje psychikę Dedalusa. Stefan stara się odnaleźć nadzieję w plątaninie ścieżek przebiegających przez miasto, ale nie potrafi uchwycić właściwej nici. Dla Dedalusa, podobnie jak dla wspomnianego Dedala, jedyną szansą dalszego życia pozostaje ucieczka z niszczącego wolność artystyczną labiryntu. Aby dostrzec perspektywy przyszłości trzeba odrzucić przeszłość, nowy świat może powstać tylko na gruzach starego. Stefan próbuje zniszczyć labirynt przestrzenny i społeczny, a tym samym pragnie uwolnić się z labiryntu podświadomości. Ucieczka, czyli porzucenie Irlandii, Dublina, rodziny, Kościoła to ostateczna szansa na wydostanie się z wszelkich ograniczeń ciasnego i dusznego miasta:

Dusza jego powstała $\mathrm{z}$ grobu chłopięctwa odrzuciwszy grobowe całuny. Tak! Tak! Tak! Dumnie stworzy z wolności i potęgi swej duszy, coś żywego, nowego i wysoko szybującego, coś pięknego, niewyczuwalnego, nieprzemijającego ${ }^{28}$.

\footnotetext{
25 V. Nabokov, Wyktady o literaturze, przeł. Z. Batko, Warszawa 2001, s. 369.

26 J. Joyce, Listy, t. 2, s. 58-59.

27 E. Naganowski, Telemach w labiryncie świata. O twórczości Jamesa Joyce'a, dz. cyt.

28 J. Joyce, Portret artysty z czasów młodości, przeł. Z. Allan, Warszawa 1997, s. 183.
} 
Tylko poprzez zerwanie pęt dziedzictwa historycznego artysta osiąga nowe, oryginalne szczyty swojej twórczości. W zaściankowym Dublinie kreatywna jednostka ginie, tracąc wszelką nadzieję na posiadanie pełnej wolności. Zniszczenie labiryntu zewnętrznego (w sytuacji Joyce'a-Dedalusa jedynym rozwiązaniem było opuszczenie Irlandii) stwarza niepowtarzalną okazję, aby uwolnić nie tylko więzione ciało, ale i duszę: „Gdy dusza człowieka narodzi się w tym kraju, zarzucają na nią sieć i hamują jej lot. Mówisz mi o narodowości, języku, religii. Postaram się wylecieć z tych sieci"29. Joyce próbuje odszukać miejsca dla siebie poza granicami Irlandii. Zostawia kraj, religię. Jednak odmienną sprawą jest opuszczenie kraju rodzinnego, a zupełnie czymś innym całkowite jego odrzucenie. Oznaczałoby to ucieczkę od samego siebie, czyli od obrazu wytworzonego w głowie i sercu człowieka. Joyce porzucił przestrzeń Dublina, ale tak naprawdę przez całe życie był w niej obecny. Kochanego i brudnego labiryntu miejskiego nie można opuścić bezkarnie i całkowicie wyrzucić z pamięci. Dublin Joyce'a jest miastem pozostawionym i jednocześnie na zawsze zapamiętanym.

Jak pisze Henri Frédéric Amiel w Dzienniku intymnym: „Każdy krajobraz jest stanem duszy" ${ }^{30}$. Przestrzeń nie istnieje sama dla siebie, lecz poprzez człowieka. Nastrój i pamięć kształtują wyobrażenia przestrzenne, krajobrazy, zarówno jednostkowe, jak i kolektywne. To nie człowiek egzystuje w przestrzeni, ale przestrzeń żyje w człowieku. Miasto charakteryzuje się szczególnie intensywną topografią uczuciową. Krajobrazów miejskich, czyli stanów duszy, jest tyle, ile osób odbiera w danej chwili bodźce zewnętrzne. Powstaje wielobarwna kompozycja wrażeniowa złożona z ogromnej ilości elementów. Na marginesie warto zaznaczyć, że niektórzy wątpią w trafność opinii Amiela o krajobrazowej moc duszy. Fernando Pessoa pytał turystów i przechodniów w Lizbonie - „(...) czemu służą te spekulacje werbalnej psychologii?" ${ }^{31}$ Może odpowiedź na wątpliwości Portugalczyka zostanie odnaleziona podczas spacerów po ulicach Lizbony. Powróćmy jednak do wrażeń wywołanych rzeczywistymi przechadzkami po ulicach Dublina.

Krajobraz urbanistyczny zmienia się z każdym krokiem i w każdej chwili. Dzisiaj dostrzegamy inną rzeczywistość niż wczoraj, mimo że krajobraz obecny ma swoje korzenie w przeszłości, a jutrzejszy zależeć będzie od nowej sytuacji, jaką stworzy człowiek. Krajobraz miejski przeobraża się odmiennie dla różnych mieszkańców. Jeden dopiero wyrusza w drogę i szuka

\footnotetext{
29 Tamże, s. 220.

30 Cyt. za: M. Janion, Żyjąc tracimy życie, Warszawa 2001, s. 63.

31 F. Pessoa, Ksiega niepokoju spisana przez Bernarda Soaresa, pomocnika księowego w Lizbonie, przeł. M. Lipszyc, Kraków 2013, s. 93.
} 
swojego celu, inny brnie do przystani w domowym zaciszu po pracowitym lub zmarnowanym dniu. $Z$ okien tramwaju widzimy te same, a jednak inne fasady domów. Człowiek stwarza swoje indywidualne miasto w codziennym, zmieniającym się świecie.

\section{Przestrzeń doświadczania}

Przestrzeń miejska nie jest zjawiskiem ciągłym, poddającym się systematycznej obserwacji badacza czy przechodnia. W jednej chwili powstają różnorodne, przypadkowe obrazy, ludzie zmieniają miejsca w przestrzeni, czasami zatrzymują się, poddają potokowi myśli lub wrażeń. Przechodzień napotyka na drodze liczne niespodzianki i tajemnice w pokawałkowanym krajobrazie. Miasto to także wydarzenia oraz ich rozmieszczenie, natężenie, kolejność i następstwa (rys. 2). Z dotychczasowych rozważań wynika, że nie istnieje jedno, konkretne miasto - tworzą je codziennie jego mieszkańcy. Tyle jest zatem miast $w$ jednym mieście, ile jest dróg, którymi jego mieszkańcy chodzą, i zdarzeń, w których uczestniczą. Zmienność wydarzeń i zachowań mieszkańców wyznacza rytm życia miejskiego. Przebiegu czasowego nie sposób oddzielić od lokalizacji zdarzeń - „Bardzo krótka przestrzeń czasu przez bardzo krótki czas przestrzeni" ${ }^{32}$. Dalej Dedalus wędruje brzegiem morza, $\mathrm{w}$ poszarpanym strumieniu świadomości, pogmatwanej przestrzeni i według przypadkowej gramatyki myślenia, w "odmierzanych krokach czasu”. Przemieszaniu ulegają także kategorie analityczne: topochronia staje się chronotopią i na odwrót.

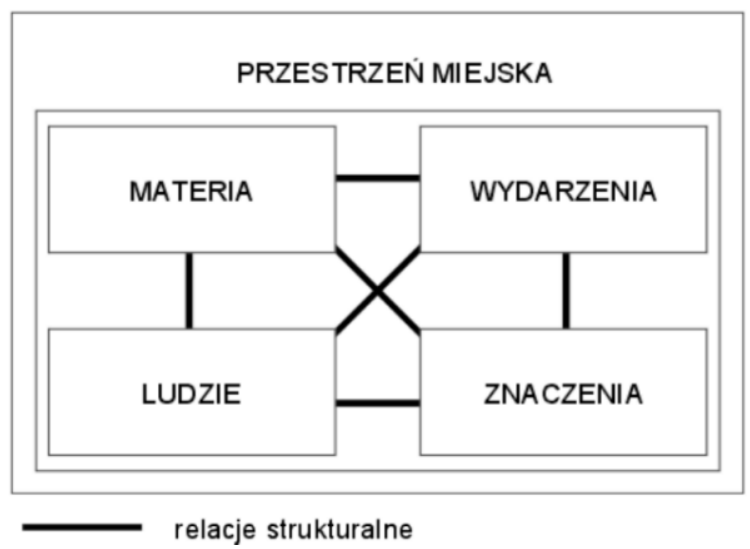

Rys. 2. Struktura przestrzeni miejskiej

32 J. Joyce, Ulisses, s. 31. 
Przestrzeń miejska konstytuuje się w umysłach ludzi na różne sposoby. W zależności od odbioru zmysłowego możemy posiadać nakreślone zupełnie inną techniką plany miast.

Pan Bloom ruszył z tyłu za bezokimi stopami i luźno skrojonym ubraniem $\mathrm{z}$ tweedu $\mathrm{w}$ jodełkę. Biedny chłopak! Jakim cudem wiedział, że ten wóz ciężarowy tam stał? Musiał go wyczuć. Może dostrzegają rzeczy czołem. Rodzaj zmysłu objętości. Ciężaru. Poczułby, gdyby coś zostało usunięte. Uczucie luki. Dziwny obraz Dublina musi mieć wystukując drogę wkoło po bruku. Czy umiałby iść prosto, gdyby nie miał tej laski? ${ }^{33}$

Niewidomy chłopak, którego Bloom przeprowadził przez Dawson Street, żyje zapewne w przestrzeni wypełnionej wrażeniami innymi niż wzrokowe.

Miasto jest synergicznym układem odczuwania zmysłowego. Odbierane wrażenia można podzielić na wskaźniki i ikony. Ikony pozwalają na identyfikację przedmiotów $\mathrm{w}$ zmiennej przestrzeni miasta i odnoszą się do podmiotu poznającego, natomiast wskaźniki są znakami służącymi do odszyfrowania zjawisk wywołanych przez dany przedmiot (np. dym i ogień). Wskaźniki i ikony nie występują oczywiście w przestrzeni miasta rozłącznie i, co istotne, posiadają charakter przypadkowy, incydentalny oraz permanentny. Przestrzeń miejska składa się zatem z migawkowych obrazów, chaotycznych, często zaskakujących zdarzeń oraz trwałych krajobrazów, które są dość stabilne w dłuższym okresie. Obraz miasta można skonstruować, posługując się takimi ikonami, jak: słuchowe, węchowe, zewnętrznie odczuwalne (dotykowe, termiczne) wzrokowe dynamiczne i wzrokowe statyczne ${ }^{34}$. Wymienione ikony powinny być rozpatrywane we wzajemnych relacjach i zmieniających się kontekstach sytuacyjnych. Mamy bowiem do czynienia z ciągle zmiennym układem ikon i wskaźników przestrzeni miejskiej.

Przestrzeń miejska to, innymi słowy, wielki koncert symfoniczny (według Bachtina raczej fuga w Bachowskiej temperacji), a reakcje słuchacza zależą od poziomu wrażliwości muzycznej. Zgoda i harmonia zmysłów pozwalają po wysłuchaniu muzyki przestrzeni ułożyć w pamięci mapę. Topografia miejsca określa następnie osobowość człowieka, powstaje jego portret. Obrazy przestrzenne są kodowane dzięki pamięci („Lecz ja, entelechia, kształt kształtów, jestem ja dzięki pamięci [...]"35). Pamięć także posiada swo-

\footnotetext{
33 Tamże, s. 139.

34 B. Jałowiecki, Proces waloryzacji przestrzeni miejskiej, w: Przestrzeń i społeczeństwo, red. Z. Pióro, Warszawa 1982, s. 101.

35 J. Joyce, Ulisses, s. 146.
} 
istą strukturę przestrzenną, a jej zapisem jest mapa - odzwierciedlenie środowiska w umyśle człowieka. Możliwe są również podróże po krajobrazie pamięci, wędrówki do miejsc pozostawiających złe i dobre ślady w ludzkich duszach.

Pamięć jako miejsce, jako budowla, jako ciąg kolumn, karnesów, portyków. Nasze ciało wewnątrz umysłu, jak gdybyśmy się w tym umyśle poruszali z miejsca w miejsce, i odgłos naszych kroków, znaczących to nasze przemieszczanie się ${ }^{36}$.

Życie człowieka nie jest zatem prostym następstwem czasu. Składają się nań okresy, kiedy uciekamy przed przeszłością oraz fazy, w których przeszłość nas dogania.

Człowiek, wędrując po ścieżkach przestrzeni realnej i przestrzeni zapamiętanej, tak naprawdę odnajduje $\mathrm{u}$ kresu drogi nie tylko poszukiwane miejsca, ale przede wszystkim samego siebie. Spotykamy siebie dzięki wydarzeniom zapisanym $\mathrm{w}$ przestrzeni. Człowiek kształtuje przestrzeń, przystosowując ją do własnych potrzeb, ale stanowi także jej zwierciadło, poprzez to, kim jest i jak się zachowuje (np. twarz pana Duffy, kasjera w prywatnym banku, „z której można było wyczytać całe dzieje jego życia, miała brązowy odcień ulic Dublina" ${ }^{37}$ ). Poznawanie przestrzeni życia człowieka to epifania jego twarzy ${ }^{38}$. Historia życia zapisuje się na naszej twarzy, powstaje swoista mapa złożona $\mathrm{z}$ wydarzeń, postaw, charakterów, pokonywanych ścieżek, zwycięstw, rutyny, przypadku, itd. W rysach ludzi odnajdziemy obrazy miejsc i odbywanych podróży. Przestrzeń maluje portret człowieka - mapę jego życia.

Ujęcie metaforyczne pozwala na wieloaspektowe opisanie przestrzeni urbanistycznej. Scena i teatr należą do częstych metafor, przedstawiających życie mieszkańców miasta i porównujących je do w spektaklu ${ }^{39}$. Ludzie wychodzą codziennie na scenę, odgrywają swoje role, wracają do domów, by ponownie następnego dnia rozpocząć przedstawienie. Spektakl musi trwać, ludzie odgrywają główne role, występują jako statyści, czasami zmienia-

\footnotetext{
36 P. Auster, Wynaleźć samotność, przeł. K. Zabłocki, Warszawa 1996, s. 77.

37 J. Joyce, Dublińczycy, s. 94-95.

38 E. Lévinas, Całość i nieskończoność, przeł. M. Kowalska, Warszawa 1998.

39 Metafora sceny bywa często wykorzystywana do przedstawiania zróżnicowanych koncepcji teoretycznych np., ujecie dramaturgiczne w socjologii, zarządzanie miastem, w nowoczesnych technikach marketingowych, por. E. Goffman, Człowiek w teatrze życia codziennego, przeł. H. i P. Śpiewakowie, Warszawa 1981; I. Sagan, Metodologiczne dylematy wspótczesnej geografii społeczno-ekonomicznej, „Studia Regionalne i Lokalne” 2000, nr 2.
} 
ją się dekoracje, a ciągle zmienny strumień aktorów przewija się przez scenę: "Całe miasto odchodzi, inne całe miasto przychodzi, też odchodzi: następne przychodzi, odchodzi. Domy, rzędy domów, ulice, całe mile chodników, spiętrzone cegły, kamienie. Z ręki do ręki. Ten właścicielem, tamten" ${ }^{40}$. Zmieniają się właściciele, przychodzą i odchodzą mieszkańcy, przestrzeń miejska ulega przeobrażeniom. Budowle zmieniają funkcje i symbolikę. Mieszkańcy tworzą sferę znaczeniową przestrzeni miejskiej, która pozwala sprawnie poruszać się w zewnętrznym labiryncie. Działania codzienne odbywają się na scenie odpowiednio oznaczonej i przygotowanej dla mieszkańców, turystów oraz innych, przypadkowych aktorów.

Każdego dnia człowiek przemierza pewien szlak w przestrzeni zmieniającego się z godziny na godzinę miasta ${ }^{41}$. Dzienna ścieżka życia Leopolda Blooma rozpoczyna się w domu przy Eccles Street nr 7 (rys. 3):

Na progu sięgnął do tylnej kieszeni po klucz od zatrzasku. [...] Ziemniak mam. [...] Przeszedł na słoneczną stronę [...] Słońce zbliżało się do wieży kościoła Świętego Jerzego. Zdaje się, że będzie ciepły dzień. W czarnym ubraniu szczególnie się to odczuwa ${ }^{42}$.

Bloom wyrusza w daleką podróż w czwartek, 16 czerwca 1904 roku. Schował ziemniak do kieszeni czarnego ubrania. Rekwizyty i kostiumy zostały przygotowane do odegrania roli na scenie Dublina - tajemniczy ziemniak i żałobne szaty. Następnie pan Bloom skierował swe kroki w kierunku Dorset Street: „Zbliżył się do Larry'ego O'Rurke. [...] Z otwartych drzwi baru buchała woń imbiru, herbacianego pyłu, pokruszonych herbatników. A jednak dobry lokal: na samym końcu wielkomiejskiego ruchu" ${ }^{\prime 3}$. Przestrzeń miasta zbudowana jest $\mathrm{z}$ wielu warstw, które docierają do zmysłów przechodnia. Miasto nie składa się wyłącznie z materialnych elementów zagospodarowania przestrzeni, ale oddziałuje na wszystkie zmysły. Na przykład róg Dorset Street i Eccles Street mijany przez Blooma ma zapach imbiry, który czytelnik może chłonąć dzięki wyobraźni. Dzisiaj dość trudno odnajdujemy kuszące zapachy wśród intensywnego ruchu ulicznego Dorset Street.

\footnotetext{
40 J. Joyce, Ulisses, s. 126.

41 J. Kaczmarek, Dzienna ścieżka życia mieszkańców Łodzi a warunki życia w mieście, Łódź 1996;

K. Faliszek, Rytm życia w przestrzeni miasta, w: Przestrzeń wielkiego miasta w perspektywie badań nad planowaniem i żywiołowościq, red. K. Wódz, Katowice 1991.

42 J. Joyce, Ulisses, s. 44.

43 Tamże, s. 45.
} 


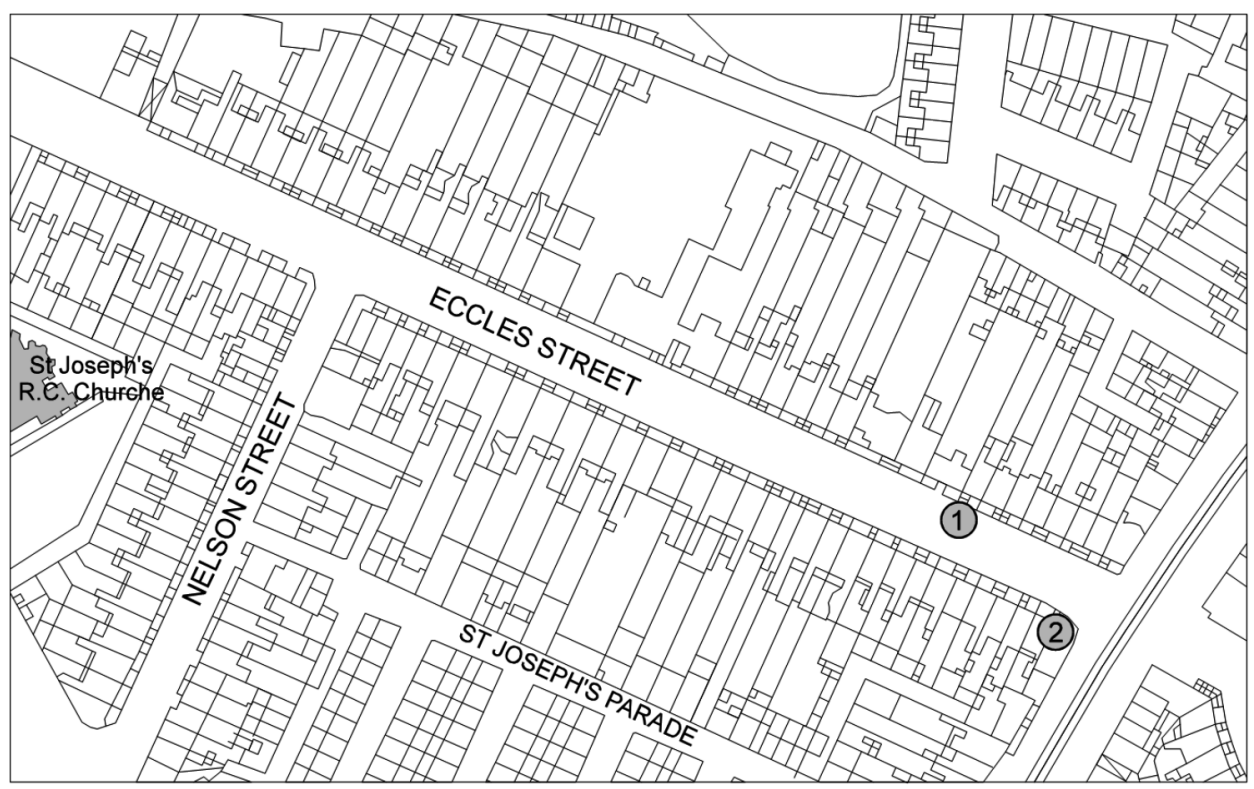

Rys. 3. Eccles street w Dublinie morfologia ulicy na początku XX wieku (1 - dom Leopolda Blooma, 2 - bar Larry'ego O'Rourke)

Miasto posiada powtarzalny rytm, powiązany z dzienną i nocną aktywnością ludzi w przestrzeni. Statyczny obraz przestrzeni miejskiej nie obejmuje różnorodności zjawisk, dopiero uchwycenie ciągłej zmienności kreuje wielozmysłowy, zadziwiający i zaskakujący film. Miasto zmienia się nieustannie, inne oblicze pokazuje mieszkańcom, odmienia fasady przed turystami, ma leniwy nastrój po „słonecznej stronie” Eccles Street i niecodzienną atmosferę $\mathrm{w}$ miejscach rozpusty.

W niezmiennie zmiennym teatrze życia miejskiego ludzie odgrywają przypisane im role, a fragmenty biografii różnych osób układają się w jeden monotonnie powtarzalny życiorys. W scenerii Dublina rozgrywa się zatem jedno życie różnych osób.

Miasto tworzą najczęściej różnorodne przestrzenie, do których można zaliczyć: przestrzeń fizyczną (otoczenie człowieka, materialne formy zagospodarowania środowiska), przestrzeń egzystencji (układ strukturalno-funkcjonalny, stanowiący ramy życia codziennego i umożliwiający mieszkańcom pełnienie właściwych ról społecznych), przestrzeń symboliczną (układ zakodowanych znaczeń zapisanych w przestrzeni miasta, będący wyrazem pamięci zbiorowej, jak i indywidualnych, intymnych przeżyć jednostki). Człowiek żyje zatem nie tylko w przestrzeni fizycznej, wyznaczającej sprawność działania systemu miejskiego, ale jednocześnie w świecie mitu, sztuki, religii, 
mistyki, kodów językowych konstruowanych i pisanych społecznie, a subiektywnie odczytywanych ${ }^{44}$. Zorganizowanie przestrzeni miejskiej wyznacza zakres indywidualnych i społecznych zachowan. W końcu struktura miasta ma swą genezę w warunkach geograficzno-historycznych.

Rozumienie "mowy” przestrzeni miejskiej zakłada traktowanie w sposób nierozdzielny topografii miasta oraz biografii jego mieszkańców. Tworzą one skomplikowaną sieć znaczeń, a pozbawione symboliki stają się pustymi przestrzeniami bez twarzy i ducha ${ }^{45}$. Odczytanie i zrozumienie nie dokonuje się $w$ jednym akcie poznania, ponieważ proces czytania, słuchania miasta może trwać nawet całe życie. Dlatego biografia i topografia łączą się w jedną całość. Napisane zostają wówczas topobiografie mieszkańca miasta, czyli księga znaczeń i uczuć emocji powstających w kolejnych miejscach ważnych dla jednostki i zbiorowości. Miejsca szczególne dla jednostki są indywidualnym zapisem pamięci w przestrzeni, natomiast pamięć zbiorowa posiada bardziej czytelną symbolikę zapisaną w morfologii i fizjonomii miasta. Podobnie język zakorzeniony bywa w przestrzeni i właśnie tam trzeba szukać jego proweniencji, traktując $\mathrm{w}$ sposób nierozdzielny topografię miasta oraz biografię jego mieszkańców. „Przeciąganie głosek stanowiło echo dublińskich nabrzeży odbite od niegościnnego i walącego się portu, a ogień - echo pobożnej elokwencji dublińskiej płasko odbite od wicklowskiej ambony"46. Język nabiera stopniowo cech świata, w którym żyje człowiek, a rozumienie języka dokonuje się przez poznanie przestrzeni, z którą słowa i gesty są nierozerwalnie związane.

Lektura miasta związana jest $\mathrm{z}$ jednoczesnym konstruowaniem jego obrazu w psychice człowieka. Tworzy się wówczas krajobraz wewnętrzny, pejzaż zrozumiały właściwie tylko dla jednostki, która buduje go w umyśle i duszy. Proces czytania miasta i konstruowanie krajobrazu wewnętrznego najlepiej można zaobserwować na przykładzie Stefana Dedalusa, który w Portrecie artysty z czasów młodości stopniowo poznaje Dublin.

Dublin wywoływał wrażenie nowe i skomplikowane [...]. Z początku zadowalał się bojaźliwym krążeniem wokół sąsiedniego placu lub najwyżej zapuszczał się do połowy jednej z przecznic; gdy jednak naszkicował sobie miasto w pamięci, szedł już śmiało jego osią aż do urzędu celnego. Nie zaczepiany przez nikogo chodził wśród doków i po nabrzeżach dziwiąc się masie korków

\footnotetext{
44 D. Jędrzejczyk, Geografia miast jako nauka humanistyczna, w: Humanistyczne oblicze miasta, red. D. Jędrzejczyk, Warszawa 2004.

45 N. Leśniewski, Miasto i jego miejsca. Próba ujęcia radykalno-hermeneutycznego, w: Pisanie miasta - czytanie miasta, red. A Zeidler-Janiszewska, Poznań 1997.

46 J. Joyce, Portret artysty z czasów młodości, s. 211-212.
} 
kołyszącej się na powierzchni wody w gęstej żółtej pianie, tłumom tragarzy portowych, huczącym wózkom towarowym i źle ubranemu, brodatemu policjantowi. [...] Nieokreślona niechęć rodziła się w nim na widok nabrzeża, rzeki i niskiego nieba, lecz mimo to wałęsał się wszędzie, dzień w dzień, jak gdyby naprawdę szukał kogoś, kto mu się wymyka ${ }^{47}$.

Początkowo nieśmiała lektura Dublina prowadzi Stefana na coraz bardziej odległe obszary, tak w sensie odległości geodezyjnej, jak i dystansu społecznego oraz oporu psychicznego. Stefan poznaje nie tylko mroczne strony życia miejskiego, ale jednocześnie zapisuje własny krajobraz wewnętrzny, złożony przede wszystkim z żądzy i namiętności. Krajobraz miasta i pejzaż wewnętrzny są nierozerwalnie ze sobą związane. Brudne, wąskie uliczki Dublina rysują podobny obraz w duszy Stefana.

Labirynt miasta często wywiera negatywny wpływ na kształt krajobrazu wewnętrznego. Człowiek, straciwszy orientację w przestrzeni miejskiej, powoli przestaje rozumieć własną psychikę.

Dostał się w labirynt wąskich i brudnych uliczek. Z cuchnących zaułków dochodziły ochrypłe, hałaśliwe głosy, sprzeczki i pijackie zawodzenia. Szedł naprzód skonsternowany, zastanawiając się, czy nie zabłąkał się do dzielnicy żydowskiej. Kobiety i dziewczęta w długich jaskrawych sukniach przechodziły przez ulicę z domu do domu, leniwe i wyperfumowane. Chwycił go dreszcz, a oczy zaszły mu mgłą. Żółte płomienie gazowe strzeliły przed jego zmąconym wzrokiem w mgliste niebo, płonąc jak przed ołtarzem. Przed drzwiami i w oświetlonych przedsionkach zebrały się grupy przystrojone jak do obrzędu. Znajdował się w innym świecie; zbudził się ze snu trwającego stulecia ${ }^{48}$.

Miasto wpływa w znaczący sposób na charakter człowieka. To oddziaływanie ma czasami charakter pozytywny, np. kształtowanie poczucia piękna w przestrzeni, i prowadzi do wytworzenia silnej więzi uczuciowej z danym obszarem - topofilia. W innej sytuacji miasto działa niszcząco na ludzką świadomość, a wtedy rodzi się nienawiść do miejsca - topofobia. Człowiek zaczyna też nienawidzić samego siebie. Chciałby uciec z miejskiego labiryntu, ale nie zawsze ma szanse na samodzielnie podejmowanie decyzji. Miasto pochłania i niszczy, przestrzeń Dublina wywiera zdecydowanie destrukcyjny wpływ na krajobraz wewnętrzny.

Stefan Dedalus odnajduje w końcu swoje miejsce w Dublinie, jest nim Biblioteka Narodowa. Kult sztuki, piękna, nauki otwiera okna na świat i pozwala bohaterowi uwolnić się z obskurnej, zaściankowej atmosfery ówczesnego Dublina. Dedalus, a właściwie sam Joyce, znajduje nareszcie swoje

47 Tamże, s. 69-70.

48 Tamże, s. 107. 
miejsce $\mathrm{w}$ niegościnnej przestrzeni, aby następnie je utracić. Na stopniach Biblioteki Narodowej Stefan rozpoczyna nowy etap podróżowania po labiryncie zewnętrznym i wewnętrznym. Następuje kolejna faza budowania krajobrazu wewnętrznego.

Stefan zatrzymał się na stopniach biblioteki [...] Więc przez wieki całe ludzie wznosili oczy ku niebu, podobnie jak on spogląda na ptaki w locie. Kolumnada nad nim przywiodła mu niejasno na myśl starożytną świątynię, kijek zaś, na którym opierał się ciężko - krzywą laskę augura. Uczucie lęku przed czymś nieznanym drgnęło $\mathrm{w}$ jego umęczonym sercu, lęku przed symbolami i oznakami, przed sokołowi podobnym mężem, jego imiennikiem, który z więzienia swego wzbił się w przestworza na wiklinowych skrzydłach ${ }^{49}$.

Stefan obserwuje wędrowne ptaki ze schodów świątyni sztuki i nauki. Także dla niego zbliża się najwyższa pora, by wyruszyć w drogę. Właśnie DROGA staje się przeznaczeniem bohaterów opisanych przez Jamesa Joyce'a. Stefan-autor Ulissesa nie ma innego wyjścia, tylko poza granicami Irlandii może być Irlandczykiem, a przede wszystkim wolnym artystą: „[...] najkrótsza droga do Tary wiedzie przez Holyhead" ${ }^{50}$. Przestrzeń Dublina wyznacza drogę fizyczną i duchową Stefana Dedalusa, od wstępnego poznawania miasta, aż po dramatyczną decyzję na stopniach Biblioteki Narodowej. Wędrówka duchowa do Tary może być zrealizowana tylko przez Holyhead. Stefan pragnie znaleźć się $\mathrm{w}$ mitycznej Tarze - centrum politycznym i duchowym do XI wieku. Odległość geodezyjna z Dublina do Tary jest znacznie mniejsza niż przez Morze Irlandzkie do Holyhead. Natomiast Stefan-Joyce miał na myśli dystans społeczny, którym nie rządzą fizyczne prawa grawitacji. I rzeczywiście, aby dotrzeć do serca Irlandii należy najpierw popłynąć do Holyhead (rys. 4).

Budowanie krajobrazu wewnętrznego poprzedza lektura miasta, podczas której następuje odkrywanie nowych wymiarów w przestrzeni fizycznej. Dystans społeczny bywa często odmiennie mierzony, niż tylko odległością fizyczną. Krajobraz wewnętrzny charakteryzuje się swoistymi miarami, nieposiadającymi odpowiednich dla nich jednostek fizycznych. Przestrzeń fizyczna i pejzaż wewnętrzny są światami o odmiennych wymiarach, ale jeden bez drugiego nie może istnieć. Świat fizyczny i świat symboliczny są skazane na siebie. Przestrzeń pozbawiona znaczeń będzie przestrzenią pustą lub wydrążoną, natomiast ludzie bez indywidualnej geografii będą jedynie turystami w swoim życiu.

\footnotetext{
49 Tamże, s. 244-245.

50 Tamże, s. 275.
} 


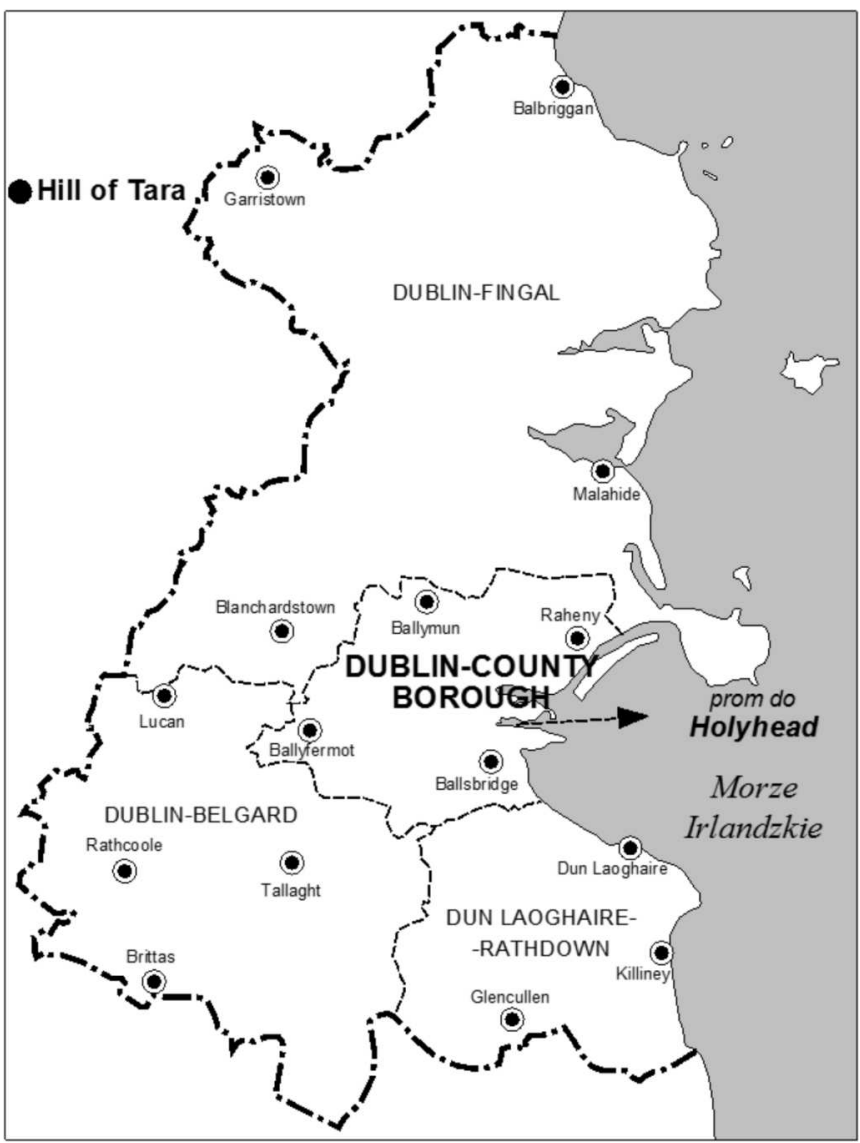

Rys. 4. Mapa Irlandii - region Dublina

Uciekający czas, płynąca woda, przyroda ze swoim dostojeństwem pozbawionym uczuć oraz zmienny i kruchy człowiek, którego ślady pozostawione $\mathrm{w}$ przestrzeni zmywa woda przypływu kolejnych wydarzeń, są powszechnymi metaforami dramatu ludzkości. Czas przyrody i czas człowieka płyną obok siebie $\mathrm{w}$ niezmiennym biegu rzeki. Człowiek zanurzony jest w strumieniu czasu i jednocześnie strumień czasu przepływa przez niego. Tajemnica zmienności ciała człowieka to zrozumienie tajemnicy przepływającego przez nie czasu, który nie jest tylko regulatorem zachowań człowieka i jego zewnętrzną rzeczywistością. Czas płynie przez człowieka i pozostawia w nim ślady swojej działalności ${ }^{51}$.

\footnotetext{
51 J. Tischner, Spór o istnienie człowieka, Kraków 1998; J. Tischner, Filozofia dramatu, Kraków
} 1998. 
Doświadczanie upływającego czasu przyrodniczego i psychologicznego dotyczy każdego człowieka. Przeżywając samych siebie, powtarzamy jednocześnie dzieje innych ludzi.

Więc to się powtarza. Myślisz, że uciekasz i wpadasz na samego siebie ${ }^{52}$.

Przechadzamy się wewnątrz siebie, spotykając zbójców, duchy, olbrzymów, starców młodzieńców, żony, wdowy, szwagrobraci. Ale zawsze spotykając samych siebie ${ }^{53}$.

Jesteśmy zatem niepowtarzalnymi indywidualnościami i jednocześnie każdym człowiekiem, który żył, jest i będzie. Wędrując w przestrzeni, widzimy innych ludzi, a tak naprawdę na każdym kroku czasu spotykamy samych siebie.

Według Joyce'a nadzieja dla człowieka tkwi w zachowaniu niezmiennie trwającej teraźniejszości. Wędrówkę pana Blooma możemy także przedstawić w precyzyjnie naszkicowanym krajobrazie urbanistycznym. Bohater-tułacz ma przy sobie ów tajemniczy rekwizyt, swoisty pomost ponad czasami i przestrzenią. Pomiędzy godziną dziesiątą a jedenastą spotkamy Blooma w dniu 16 czerwca w krainie Lotofagów.

Wyjął list z kieszeni i włożył go do gazety, którą niósł. [...] Skręcił w Cumberland Street i przeszedł kilka kroków, przystanął pod osłoną dworca kolejowego. Nikogo. Skład drzewa Meade'a. Stosy belek. Ruiny i budynki. Ostrożnie przekroczył placyk do gry w klasy wraz z pozostawionym kamykiem. Żywej duszy. Nie opodal składu drewna dziecko przykucnęło, grając w kulki, samotne, uderzając w nie zagiętym kciukiem. Mądra bura kotka, mrużący oczy sfinks, przyglądała się ze swego ciepłego parapetu. Nie trzeba im przeszkadzać ${ }^{54}$.

Zatrzymana chwila okolic dworca Westland Row rozgrywa się tam niezmiennie. Akcja nierozerwalnie łączy się z przestrzenią. Dlatego Joyce tak precyzyjnie opisywał dubliński krajobraz, przewidując, że zniszczenie przestrzeni unicestwi wydarzenia, które miały tam miejsce.

Przedstawiane zdarzenia, opisana przestrzeń należą jednak zawsze do autora, a czytelnik chwyta jedynie cień takiej chwili we własnej interpretacji tekstu. Joyce został w Dublinie początków stulecia ze swoimi bohaterami. Larry O'Rurke cały czas opiera się o worek z cukrem, a bura kotka niezmiennie obserwuje Leopolda Blooma, który ostrożnie otwiera ukryty w gazecie list. Uważny czytelnik i ostrożny wędrowiec odnajdą autentycznych

\footnotetext{
52 J. Joyce, Ulisses, s. 293.

53 Tamże, s. 164-165.

54 Tamże, s. 60.
} 
ludzi oraz miejsca, wszak każda nieobecność może mieć wyłącznie przestrzenny charakter ${ }^{55}$.

Na kartach Finnegansów trenu bohaterowie opuszczają realną przestrzeń miejską i wypływają na ocean snu w mitycznym Dublinie (jest to jedna z możliwych interpretacji niepowtarzalnego „dzieła w toku”). Autor pozbywa się zupełnie ograniczeń przestrzenno-czasowych i pozwala swobodnie żeglować dublińczykom w krainie snów. Na szczególną uwagę zasługuje pierwsze i ostatnie zdanie Finnegansów trenu, a właściwie jedno zdanie zapisane w odwrotnym porządku. Książka rozpoczyna się od drugiej części zdania: „rzeki brzeg, postephując od Ewy i Adama, od wygięcia wybrzeża do zakola zatoki, zanosi nas znów przez commodious vicus recyrkulacji pod Howth Castle i Ekolice" ${ }^{26}$, kończy się zaś jego pierwszą częścią, która brzmi: „Ach w dal a ląd a los a lot a cel gdzie" 57. Początek staje się końcem, a zakończenie początkiem. Wszelki porządek czasu i przestrzeni przestaje odgrywać rolę. Topografia Dublina została opisana przez Joyce'a bardzo dokładnie, natomiast przemieszczanie się mieszkańców i następstwo czasu są już swobodną grą. Symultaniczna przestrzeń miasta, pogrążonego w marzeniach śniących ludzi, odkrywa możliwości kreowania takich zjawisk, których nie daje się systematycznie badać, a ich istnienie nie jest do końca pewne. Zdarzenia trwają, przemijają i następnie powracają. Wszystko właściwie nieustająco zmienia się, trwa wiecznie, bez końca i początku. Bohaterowie Joyce'a krążą nieustannie pomiędzy realną przestrzenią Dublina oraz "drugą przestrzenią" - wyobrażoną. Mit u Joyce'a miesza się z rzeczywistością, bohaterowie rozpływają się we mgle, przesłaniającej indywidualność jednostki. Można powiedzieć, że wszystkie postaci występujące w Finneganów trenie są Joycem i jednocześnie Joyce jest we wszystkich swoich bohaterach. Cały świat znajduje się w nich i ci bohaterowie są całym światem.

\section{Trwanie miasta, czyli topochronia}

W naukach geograficznych mamy do czynienia z nurtem scjentystycznym (stanowisko empiryczne) i antyscjentycznym (stanowisko nieempiryczne). Wykorzystanie podejścia naturalistycznego pozwala precyzyjnie, stosując odpowiednie miary, opisać przestrzeń (lokalizacje, relacje, mobilność). Badacz empirysta pragnie odkryć wszelkie tajemnice ukryte $\mathrm{w}$ zjawiskach

\footnotetext{
55 A.B. Cesares, Wynalazek Morela, przeł. A. Nowak, Kraków 1975.

56 J. Joyce, Finneganów tren, przeł. K. Bartnicki, Kraków 2012, s. 3.

57 Tamże, s. 628.
} 
przestrzennych. Dąży on jednocześnie do sformułowania ogólnych prawidłowości, które rządzą badanymi procesami. Natomiast geograf humanista pozostawia, przynajmniej częściowo, nie wyjaśniony świat. Przestrzeń posiada swoje tajemne miejsca, pewną zagadkową sferę. Badacz humanista nie opisuje każdego zjawiska, nie mierzy wszystkiego. Próbuje zrozumieć świat poprzez poznanie samego siebie oraz miejsca innych ludzi w tymże świecie.

Ograniczenie sposobów badania środowiska geograficznego wyłącznie do jednego stanowiska naukowego nie pozwala w pełni wyjaśnić zachowań przestrzennych człowieka. Zrozumienie przestrzeni powinno postępować jednocześnie niezależnymi drogami, ponieważ różne podejścia metodologiczne stwarzają szanse na uzyskanie komplementarnych obrazów (tab. 2).

\section{Tabela 2.}

Poziomy poznawcze przestrzeni miejskiej (PPPM)

\begin{tabular}{|c|c|c|}
\hline PPPM & Ogólny & Indywidualny \\
\hline $\begin{array}{l}\text { Obiektywny } \\
\text { Subiektywny }\end{array}$ & Miejskość & Miasto \\
Teksty kultury & Świat życia człowieka \\
\hline
\end{tabular}

Źródło: J. Kaczmarek ${ }^{58}$.

Przestrzeń miasta posiada odmienne oblicza i dopiero prowadzenie badań na odpowiednich poziomach poznawczych umożliwia zrozumienie zjawisk w niej zachodzących. Kategoria „miejskość” dotyczy studiów, których celem jest przedstawienie uniwersalnych cech przestrzeni urbanistycznej, czyli uchwycenie pewnej niezmienności charakterystycznej dla wszystkich miast ${ }^{59}$. Na przestrzeń Dublina należy zatem spojrzeć jako na uniwersalną ideę miejskości, syntezę miasta-miast. Joyce w swoich utworach zapisał koncepcję miejskości w postaci labiryntu i splotu biografii mieszkańców.

Kolejnym krokiem prowadzącym do zrozumienia miejskości jest analiza warunków geograficzno-historycznych, wpływających na powstanie (także upadek) konkretnych miast. Wszak każde miasto pozostaje inne w swej niezmiennej zmienności.

Tekst (także film), podobnie jak mapa dla środowiska geograficznego, jest syntetyczną formą zapisu topografii kultury $\mathrm{w}$ danym czasie (new to-

\footnotetext{
58 J. Kaczmarek, Dublin - labirynt nad rzeka, s. 343.

59 S. Liszewski, Przestrzeń miejska i jej organizacja, w: Geografia, człowiek, gospodarka, red. B. Domański, A. Jackowski, Kraków 1997; H.J. Gans, Urbanism and Suburbanism as Ways of Life: A Re-evaluation of Definitions, w: Sociology: A Biographical Approch, red. B. Berger, P.L. Berger, New York 1972.
} 
pography ${ }^{60}$. Ostatecznie „środowisko życia człowieka" może być rozumiane jako tworzenie własnego świata na podstawie tekstów literackich. Znaczenie tekstu dla czytelnika, według Gadamera, polega nie tylko na poznawaniu odległej rzeczywistości historycznej, ale na reprezentacji przeszłości w indywidualnej teraźniejszości, w świecie życia codziennego każdego człowieka ${ }^{61}$. Dlatego też opisany przez Joyce'a Dublin należy także do czytelnika, wędrowca odwiedzającego to miasto. Jest to MÓJ DUBLIN - może powiedzieć każdy niespieszny podróżny wpatrujący się w nurt Liffey. Tamten Dublin był i jest w dalszym ciągu sceną Joyce'a i jego bohaterów. O'Rurke będzie opierał się nadal o worki, pod wiaduktem spotkamy burą kotkę, ilekroć postanowimy pomaszerować na dworzec kolejowy Westland Row.

Dotychczasowe rozważania prowadzą do pytania o to, jakim zjawiskiem jest miasto? Lektura utworów Joyce'a pozwala sformułować następującą odpowiedź: miasto jest niezmiennie zmienną przestrzenią, indywidualnie kształtowaną przez warunki geograficzno-historyczne (każde miasto posiada swoją odmienność) oraz subiektywnie przeżywaną przez mieszkańców, przybyszów, czytelników.

Wśród wielu wątków poruszanych przez Joyce'a duże znaczenie ma zagadnienie wzajemnych relacji pomiędzy miastem i człowiekiem. Przestrzeń miasta powstała $w$ rezultacie aktywności człowieka i zarazem oddziałuje na zachowania mieszkańców. Ludzie nabierają cech otoczenia, w którym żyją. Ich postawy, charakter, słowa, przyzwyczajenia są odzwierciedleniem krajobrazu miejskiego, tego najbliższego otoczenia mieszkańców miast. Ponury, brudny, zaniedbany Dublin odbija się w twarzach i postawach dublińczyków. Miasto przypomina labirynt-więzienie, ale jednocześnie daje nadzieję, ponieważ w krajobrazie urbanistycznym można zapisać fragmenty życia dublińczyków, a przedstawione zdarzenia przejdą do wiecznej teraźniejszości: „wiekuiście zmienne szlaki wiekuiście niezmiennej przestrzeni" 62. Studiowanie utworów literackich pozwala poznawać i zrozumieć miasto przedstawione poprzez epizody ludzkiego życia. Dublin zapisuje się w dublińczykach, a mieszkańcy zapisują się w przestrzeni miasta. Joyce na zawsze pozostał dublińczykiem i Dublin zapisał się w jego życiorysie. Dublin pozostanie niezmiennie przestrzenią Joyce'a, a czytelnik (wędrowiec) może skonstruować indywidualny krajobraz urbanistyczny w wiecznie zmiennym czasie. Joyce precyzyjnie opisał dubliński krajobraz, przewidując, że znisz-

\footnotetext{
60 A. Charlesworth, A corner of a foreign field that is forever Spielbergs's: understanding the moral landscapes of the site of the former KL, "Cultural Geographies" 2004, nr 11.

61 K. Rosner, Hermeneutyka jako krytyka kultury, Warszawa 1991, s. 188-191.

62 J. Joyce, Ulisses, s. 521.
} 
czenie przestrzeni unicestwi wydarzenia, które miały tam miejsce. Zatrzymana chwila ma precyzyjną lokalizację $\mathrm{w}$ dziejach bohaterów oraz położenie $\mathrm{w}$ przestrzeni miasta, nad szarą, niezmiennie połyskującą, płynącą zygzakiem Liffey. Chwile zatrzymane przez Joyce'a na ulicach Dublina łączą to, co było, z tym, co będzie, to, co widzimy, z tym, czego nie potrafią dostrzec nasze oczy.

\section{Literary Recording of Space in the Context of City Lasting as in the Example of Dublin \\ Summary}

This article offers an analysis of the real space of Dublin and the narration space of the city depicted in James Joyce's novels. The groundwork of the reflections is Mikhail Bakhtin and Jean-Paul Ferrier's concepts, where literary research and geographical research play complementary roles in the process of discovering and understanding the city space.

Keywords: city space, chronotope, topochromia, topography, James Joyce 